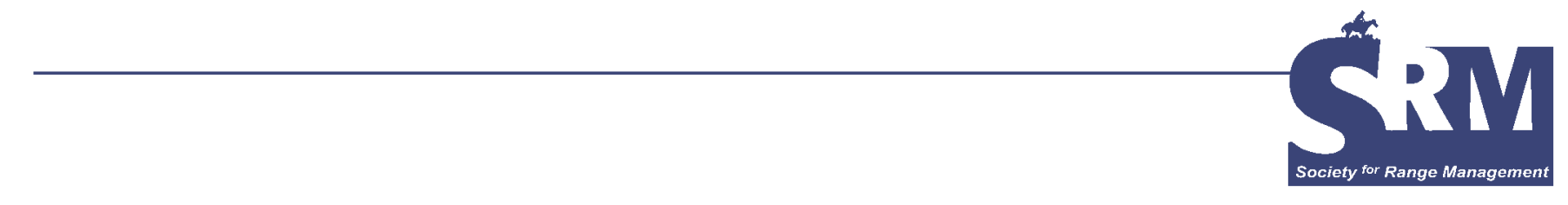

\title{
Do Micro-Nutrient Seed Treatments Assist in Range Restoration Efforts?
}

\section{Resource managers are frustrated at the lack of seedling success using conventional methodologies and thus have turned to other approaches such as using seed treatments.}

\section{By Charlie D. Clements and James A. Young}

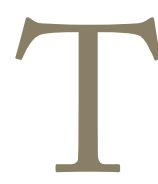

he effort to restore disturbed sites and mitigate environmental degradation consumes a considerable amount of a natural resource manager's time. In arid and semiarid environments, restoration seedings are often very difficult to establish. Resource managers are frustrated with the lack of seedling success after using conventional methodologies and have started using nonconventional methodologies such as propriety seed treatments. The exact nature of these propriety products is often confidential, but they generally consist of either nutrient or micronutrient enrichment or inoculation with unspecified microorganisms. One of the more popular propriety seed treatments used in Nevada is known as GERM-N-8 ${ }^{\circledR}$. This product is a suspension of nutrients (14\% phosphorous, $3 \%$ potassium, and $2 \%$ nitrogen) applied to dry seed at a rate of 6.5 ounces per 100 pounds of seed. The cost of using this product can range depending on the contract, but estimates run in the neighborhood of 10 cents per pound of seed if you apply the product yourself to 20 cents per pound of seed if the contractor applies the product.

Nevada experienced extreme fire conditions in 1999, when 1.8 million acres of rangelands burned (Fig. 1). The most extensive restoration/revegetation effort in history began with $\$ 60$ million being obligated over a 2-year period in Nevada alone. Within these 1.8 million acres of charred rangeland,

This article has been peer reviewed.

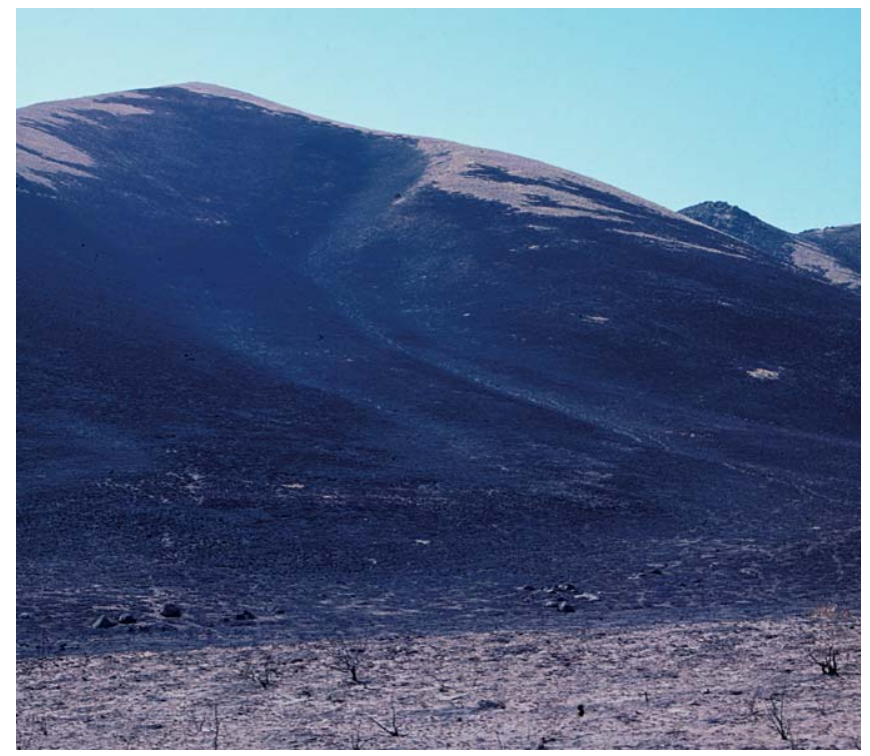

Figure 1. A small portion of the 1.8 million acres of rangelands that burned in Nevada in 1999.

over 1,100 separate fires burned more than 140,000 acres of sage grouse habitat that consisted of nearly 40 sage grouse leks, and another 700,000 acres of mule deer and antelope habitat. More than 1,500 wild horses were removed from the charred rangeland, and livestock operations were faced with the hard reality of finding alternative grazing resources away from these charred rangelands that would be closed from 


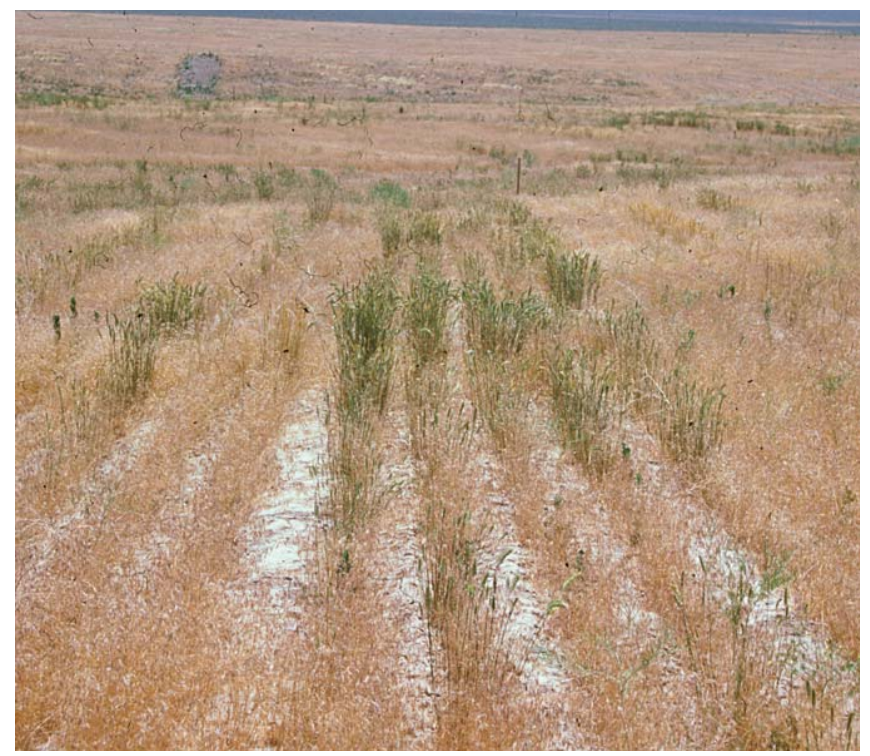

Figure 2. Many seeding efforts failed following the 1999 wildfire restoration/revegetation efforts.

grazing for at least 2 years. This massive restoration/revegetation effort resulted in the purchase of 4.8 million pounds of native and nonnative seed (1.4 million pounds of native seed at an average of $\$ 7.75 /$ pound, and 3.4 million pounds of nonnative seed at an average of $\$ 1.99 /$ pound) to be seeded on approximately 800,000 acres. In the fall of 2000 and the spring of 2001 the Winnemucca District of the Bureau of Land Management, US Department of Interior, seeded more than 900,000 pounds of grass, forb, and shrub seed treated with GERM-N-8 ${ }^{\circledR}$ at an added cost of more than $\$ 190,000$. Success of using this propriety product varies greatly among resource managers' reports: some report excellent success, some report initial success with no long-term benefit, and others report no success (Fig. 2). The lack of experimental design makes it impossible to assign cause and effect of such successes and failures.

\section{Perennial Grass Emergence and Establishment}

We tested the propriety product GERM-N-8 ${ }^{\circledR}$ on the emergence and establishment of 8 native and 1 nonnative perennial grasses at 2 locations in northwestern Nevada. The native perennial grass species tested were big bluegrass, Idaho fescue, thickspike wheatgrass, squirreltail, western wheatgrass, needle-and-threadgrass, Indian ricegrass, and bluebunch wheatgrass. Crested wheatgrass was the nonnative species tested (Table 1). Dry seed of these species were treated with GERM-N- ${ }^{\circledR}$ at the recommended rate of 6.3 ounces per 100 pounds of seed. Treated and untreated seed of each species was seeded by hand in October 2001 at a rate of 12 seeds per foot and replicated 3 times at the 2 locations. The first location, known as Beddell Flat, is 30 miles north of Reno, Nevada. At 5,080 feet elevation, the site received an average of 8.5 inches of precipitation per year as indicated by a rain gauge at the study site. The site is dominated by
Wyoming sagebrush, Nevada ephedra, and an understory of Thurber's needlegrass. The second location is about 30 miles north of Reno, and is known as Granite Peak. The site is at a higher elevation of 5,840 feet, received an average of 10.6 inches of precipitation, and is dominated by mountain big sagebrush, with an understory of Thurber's needlegrass, Idaho fescue, and squirreltail. Treatments were sampled monthly from November 2001 through August 2003 as initial sprouting, mortality, and persistent establishment were recorded. The initial sprouting of squirreltail, thickspike wheatgrass, Indian ricegrass, and bluebunch wheatgrass was more successful at the Beddell Flat site when treated with GERM-N- $8^{\circledR}$, but this only held true for squirreltail and Indian ricegrass at the Granite Peak site (Table 2). After 2 years, the persistent establishment of treated seeds was less than that of the seeds not treated, except for Indian ricegrass at the Granite Peak site. It was interesting to compare the

\section{Table 1. Common and scientific names of} plant species tested

\begin{tabular}{|c|c|}
\hline Common & Scientific \\
\hline Big bluegrass & Poa secunda \\
\hline Bluebunch wheatgrass & Pseudoroegneria spicata \\
\hline Crested wheatgrass & Agropyron desertorum \\
\hline Idaho fescue & Festuca idahoensis \\
\hline Indian ricegrass & $\begin{array}{l}\text { Achnatherum } \\
\text { hymeniodes }\end{array}$ \\
\hline Needle-and-threadgrass & Hesperostipa comata \\
\hline Squirreltail & Elymus elymoides \\
\hline Thickspike wheatgrass & Elymus lanceolatus \\
\hline Western wheatgrass & Pascopyrum smithii \\
\hline Antelope bitterbrush & Purshia tridentata \\
\hline Basin big sagebrush & $\begin{array}{l}\text { Artemisia tridentata ssp. } \\
\quad \text { tridentata }\end{array}$ \\
\hline "Immigrant" forage kochia & Kochia prostrata \\
\hline Mountain big sagebrush & $\begin{array}{l}\text { Artemisia tridentata ssp. } \\
\text { vaseyana }\end{array}$ \\
\hline Wyoming big sagebrush & $\begin{array}{l}\text { Artemisia tridentata ssp. } \\
\text { wyomingensis }\end{array}$ \\
\hline
\end{tabular}


conversion of initial sprouting to establishment between treated and untreated seeds; certain species had more initial sprouting of seedlings, but also more die-off and subsequently less establishment. This was most apparent with thickspike wheatgrass at the Beddell Flat site. The initial sprouting of treated thickspike wheatgrass seeds was 5.8 seedlings per foot compared to 4.1 of the untreated seeds, yet the establishment was 0.6 seedlings per foot when treated compared to 1.6 seedlings per foot when not treated. Again, using the propriety seed treatment product GERM-N- $8^{\circledR}$ benefited initial sprouting of some perennial grass species over those untreated, but the establishment of these perennial grass species did not benefit from this treatment at these study sites.

\section{Shrub Emergence and Establishment}

When we first started indicating our preliminary results of the perennial grass experiments, comments arose suggesting that the success that resource managers were referring to was with shrubs such as sagebrush and "Immigrant" forage kochia. Subsequently we tested the application of GERM$\mathrm{N}-8^{\circledR}$ on 5 species of shrubs at the same 2 sites in northwestern Nevada. The 3 common big sagebrush species: mountain, Wyoming, and basin big sagebrush were tested, as well as the commonly used "Immigrant" forage kochia, and the critical browse species antelope bitterbrush (Table 1). Dry seed of these species were treated with the recommended rate of GERM-N- $8{ }^{\circledR}$ and seeded in October 2003. Using 3 replications at each site, the sagebrush species and forage kochia were seeded at a rate of 20 seeds per foot, and antelope bitterbrush was seeded at a rate of 12 seeds per foot. The Beddell Flat site received an average of 10 inches of precipitation over the 2 years (2003-2004 and 2004-2005), whereas the Granite Peak study site received an average of 13.6 inches. There was no significant difference in initial emergence of shrubs

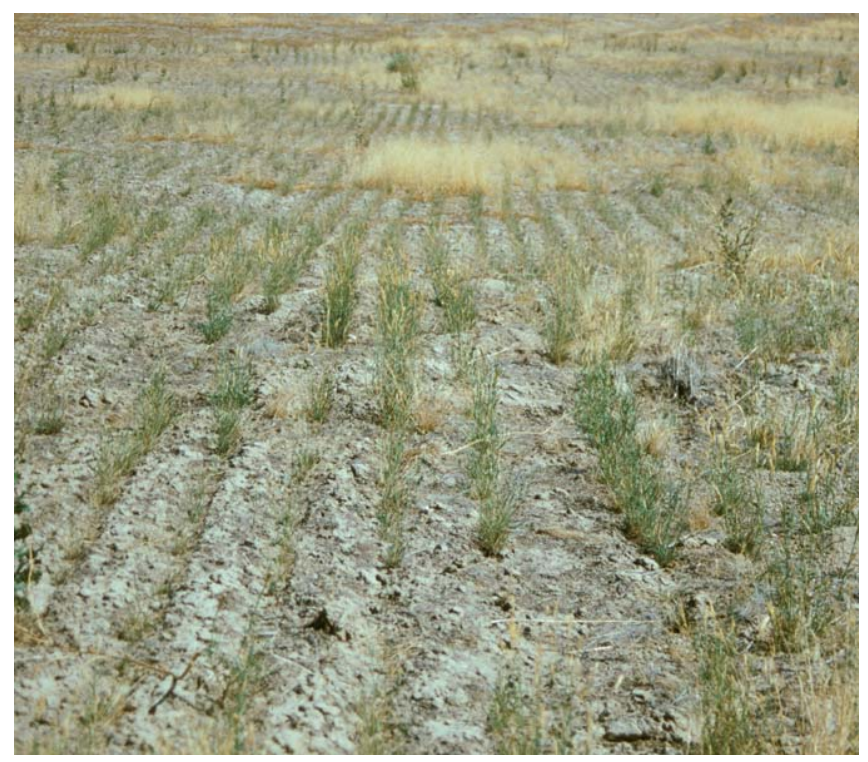

Figure 3. Initial emergence of the perennial grass, crested wheatgrass.
Table 2. A comparison of established plants per foot of row using treated and untreated seeds at the Granite Peak plots

\begin{tabular}{|c|c|c|}
\hline Species & Treated & Untreated \\
\hline Big bluegrass & 25 & 2 \\
\hline Bluebunch wheatgrass & 0.25 & 0.75 \\
\hline Crested wheatgrass & 2.50 & 4.50 \\
\hline Idaho fescue & 0 & 0 \\
\hline Indian ricegrass & 0.50 & 0.25 \\
\hline Needle-and-threadgrass & 2.25 & 3.25 \\
\hline Squirreltail & 0.25 & 0.25 \\
\hline Thickspike wheatgrass & 1 & 1.25 \\
\hline Western wheatgrass & 0.50 & 2 \\
\hline Antelope bitterbrush & 0.02 & 0.02 \\
\hline Basin big sagebrush & 0.07 & 0.19 \\
\hline "Immigrant" forage kochia & 0.06 & 0.06 \\
\hline Mountain big sagebrush & 0.08 & 0.13 \\
\hline Wyoming big sagebrush & 0.13 & 0.19 \\
\hline
\end{tabular}

between treated and untreated seeds, other than with Wyoming big sagebrush, which was twice as dense when treated with GERM-N- $8^{\circledR}$ at the Beddell Flat site, 0.04 compared to 0.02 seedlings per foot, and 3 times as dense at the Granite Peak site, 0.33 compared to 0.10 seedlings per foot. "Immigrant" forage kochia had good initial emergence at the Granite Peak site ( 0.40 untreated and 0.33 treated per foot), but significantly decreased during the summer to 0.06 seedlings per foot for both treated and untreated plots. The shrub seeding at the Beddell Flat site was a complete failure; the only established plants after 2 years were the untreated Wyoming big sagebrush (0.003 per foot) and the treated and untreated mountain big sagebrush (0.01 seedlings per foot). The Granite Peak site experienced better success; treated and untreated seeds of all species established in the plots. Mountain big sagebrush experienced the best success with an 


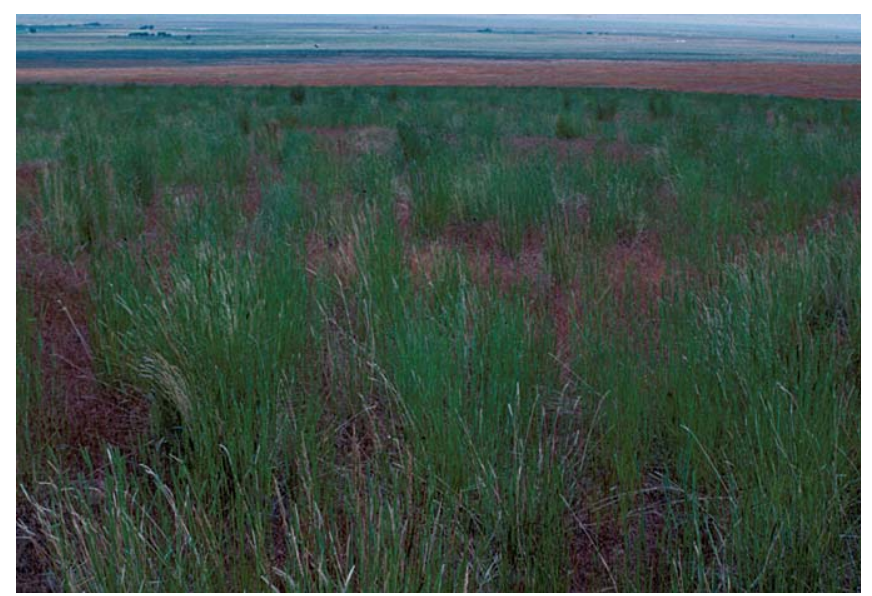

Figure 4. The establishment of perennial grasses is critical to the suppression of the highly invasive exotic annual weed, cheatgrass. The suppression of cheatgrass decreases the fuel load and frequency of wildfire which is needed to allow for the return of shrubs and other native plant species.

establishment of 0.19 seedlings per foot in untreated plots and 0.13 seedlings per foot in treated plots.

Remember, shrubs are naturally spaced at larger distances than are herbaceous grass species, so it is important to look at the plant community as a whole to get a better picture of just how our seeding compares to that of the adjacent, already established plants. For example, at the Granite Peak site the adjacent community has a density of 130,680 perennial grasses per acre. Our seeded perennial grasses have a density of 35,930 per acre. The shrub density at Granite Peak in the adjacent community, mainly mountain big sagebrush and antelope bitterbrush, is 7,380 per acre compared to our seeding that resulted in 305 shrubs per acre. The adjacent plant communities are made up of plants of various ages, whereas our plots are made up of plants on their second year. Over time, these established plants are very important in the restoration process of plant communities because they produce seed for the recruitment of plants in future years (Figs. 3 and 4). Far too often, plant communities damaged by wildfires are not seeded, and in the case of big sagebrush, the seed source is absent and there is no hope for shrubs to get established.

The treatment of these shrub species with GERM-N-8 ${ }^{\circledR}$ was not found to be beneficial in the establishment of more shrubs in this study, although the increase in the initial sprouting of some perennial grasses is worth further investigation. Resource managers need to realize that the added costs of using such propriety products may not increase their success in restoration efforts, but if they are going to use such treatments, they should scientifically collect data and maintain records that allow them to make informed decisions in the future.

Authors are Range Scientists, US Department of AgricultureAgricultural Research Service, 920 Valley Road, Reno, NV 89512, charlie@scs.unr.edu. 